\title{
Narrativas de uma imigração esquecida: imagens, escolhas e percursos da imigração de mulheres brasileiras na Itália
}

\author{
Luís Fernando Beneduzi*
}

\begin{abstract}
A figura da mulher brasileira tem ocupado o lugar do exótico e tem vivido um processo crescente de sexualização no imaginário europeu contemporâneo, como relata Pontes (2004) referindo-se à imagem das brasileiras na mídia portuguesa. Em um importante percentual, os trabalhos hodiernos que discutem as experiências de vida e/ou estruturam uma análise de pesquisa qualitativa, enfatizando narrativas sobre o quotidiano, têm relatado casos e situações de fronteira, envolvendo a prostituição, a criminalidade, os jogos de afetividade, ou seja, o sexo como instrumento de ascensão social e/ou integração na comunidade de acolhida (Machado, 2004; Piscitelli, 2008; Leonini, 2004). Segundo Piscitelli (2007), a década de 1990, na Itália, será caracterizada por um forte crescimento na circulação de mulheres estrangeiras que ofereciam prestações sexuais, sendo que as brasileiras ocupavam predominantemente os espaços fechados, em um nível social intermediário da prostituição.

O fenômeno imigratório brasileiro, na Europa, considerando as temáticas de pesquisa, está marcado pela ilegalidade, pelo desvio. De uma certa maneira, os estudos de caso não deixam de seguir um filão temático que se sedimentou no senso comum europeu e acabou pouco a pouco ocupando o lugar da complexidade do real, a partir de um conjunto de representações estereotipadas e simplificadoras da experiência de
\end{abstract}

* Professor de História e Instituições da América Latina da Università Ca’ Foscari di Venezia, Itália. 
expatriação. Efetivamente, pensando no caso específico da Itália, quando se fala em Brasil - e os noticiários atuais reforçam essa imagem - salta à mente o efeito da prostituição, sendo atualmente enfatizada aquela de transexuais. O caso clamoroso que chamou a atenção da mídia para esse submundo, ocupado em grande parte por imigrantes provenientes do Brasil, está vinculado a um misto de drogas e de encontros com transexuais que envolveu o hoje ex-presidente da Região Lazio, Piero Marrazzo.

Percebe-se que essa representação sobre a brasilidade está vinculada objetivamente a fragmentos do real, que são montados e agrupados em um processo de elaboração de um determinado olhar lançado à experiência vivida. Como afirma Baczko (1991), as representações da realidade social partem de um caudal simbólico que funciona como o núcleo duro de seu processo de sedimentação, habitando os recantos mais profundos de sua existência concreta e, finalmente, sendo parte viva e criativa na construção do próprio real, tal como ele é percebido social e individualmente:

Estas representações da realidade social [...] inventadas e elaboradas com materiais tomados do caudal simbólico, têm uma realidade específica que reside em sua própria existência, em seu impacto variado sobre as mentalidades e os comportamentos coletivos, nas múltiplas funções que exercem na vida social. [...] todo poder se acerca de representações, símbolos, emblemas etc., que o legitimam, o engrandecem e que necessita para assegurar sua proteção (Baczko, 1991, p. 8).

Essa ênfase nos estudos relacionados ao desvio que caracteriza as pesquisas sobre a imigração brasileira contemporânea na Europa está permitindo justamente a discussão desses estereótipos sedimentados e enraizados no imaginário europeu. Todavia, abre pouco espaço para trazer à luz a complexidade do próprio fenômeno imigratório, o qual também é constituído por grupos que decidem emigrar como uma escolha de ascensão social ou como a concretização de um sonho: pessoas que não partem empurrados por uma situação desesperadora, mas que analisam e projetam o próprio ato de emigrar.

Diferentemente dos estudos sobre a imigração europeia que chegou ao Brasil entre o final do século XIX e o início do XX - que se caracterizou por análises que faziam emergir narrativas sobre a vida dos imigrantes que 
deram certo, tendo sofrido somente nas últimas décadas uma mudança no eixo de discussão - as pesquisas sobre a imigração brasileira contam as trajetórias daqueles indivíduos caracterizados pela singularidade do mundo da ilegalidade. Mesmo as imigrantes nordestinas estudadas por Piscitelli (2007), que se casaram com homens italianos, trazem consigo a marca do mundo da prostituição, ambiente - no Nordeste brasileiro - onde conheceram seus maridos. Essas mulheres já trazem em seus corpos as marcas do estigma que deverá ser afrontado em âmbito doméstico, com os membros da família alargada, e na esfera social, entre amigos e conhecidos.

Procurando complexificar a realidade de análise sobre a imigração hodierna na Europa, que se caracteriza por diversas perspectivas econômicas, mas também sociais e culturais, busca-se perceber quais são os elementos detonadores, entre mulheres da classe média brasileira, do "desejo de emigrar", que tipos de representações elas tinham construído sobre a Itália no momento anterior à imigração e como essas imagens vão se reelaborando em um confronto com a realidade da "chegada". É importante ter presente que a decisão de emigrar das entrevistadas foi fruto de uma escolha pessoal e que a partida específica para a Itália esteve marcada por uma análise de diferentes espaços de imigração, sendo a preferência determinada por estratégias individuais que significavam aprimoramento profissional e apoio logístico.

Antes de continuar, deve-se fazer uma breve apresentação das duas informantes que servirão de cicerones nesse caminho pelos meandros de uma imigração "comum", a qual retrata os anseios de uma camada média da população brasileira. Inês (AHE) e Helena (VBK) - nomes que utilizaremos para denominar as depoentes - são naturais do Sul do Brasil, a primeira de Santa Catarina e a segunda do Rio Grande do Sul, e ambas possuíam instrução superior e um emprego estável quando decidiram emigrar. Poder-se-ia dizer que a situação econômica das duas era boa e estável, melhor no caso de Inês, que poderia ser qualificada como uma mulher de classe média alta. Não foi uma necessidade econômica que as empurrou para a emigração, mas a busca de uma transformação na vida - em um caso, como fruto de uma experiência anterior de emigração, na esteira de uma paixão, em outro, como a ação do acaso em uma elaboração involuntária da partida.

O leitor pode se perguntar sobre quais são as possibilidades de elaboração de uma cartografia do real considerando apenas duas histórias de 
vida, como elas podem dar conta da complexidade das relações sociais e como elas podem trazer à luz elementos que norteiam um fenômeno amplo como os processos imigratórios internacionais. Nesse sentido, é importante perceber que a narrativa de cada trajetória do vivido transcende à esfera individual/pessoal e constitui-se em uma janela para molduras de referência que clarificam uma realidade mais extensa, na qual o entrevistado está inserido. Os fragmentos narrativos que serão apresentados no texto, como se poderá notar, oferecerão - no bojo dos processos individuais de imigração - o reflexo de ideias-imagens que iluminam uma experiência coletiva dos sentimentos e das expectativas que norteiam as migrações internacionais: Inês e Helena, ao falarem de si, falam, também, de seus grupos sociais e de seus círculos culturais e afetivos. O elemento narrativo é forjado por unidades indivisíveis que se presentificam no ato da comunicação da vivência do informante (ALBERTI, 2004). Com efeito, a extrapolação da pessoalidade se realiza a partir desses componentes narrativo-imagéticos que demarcam um sentido de pertencimento geracional, profissional, social, de instrução. Certamente, essas molduras que são utilizadas como expressão da experiência individual evidenciam elementos que inundam o espaço das subjetividades: sensações, representações, percepções, sentimentos.

Por outro lado, como premissa nesta leitura de percursos imigratórios, e no trabalho com os History Tellers, entende-se que a experiência do imigrante se constitui em um espaço-tempo de transformação e de reconstrução mnemônica da história de vida pessoal, sendo o presente do sujeito entrevistado um componente fundamental para a estruturação de sua leitura do passado. Como afirma Grele (2007), a fala do entrevistado é direcionada para o presente e, ao mesmo tempo, na medida em que narra o passado, revela-o a partir da realidade que o circunda. Dessa forma, as falas das imigrantes brasileiras estarão marcadas por duas realidades que se entrecruzam e se contrapõem.

No que se refere ao contexto social, o momento em que as entrevistas foram feitas coincide com o início de um processo de crescimento de uma ideia negativa da figura do extracomunitário ${ }^{1}$, a representação

1 Para uma discussão sobre o processo de negativização do conceito de "extracomunitário", remete-se a Beneduzi, 2009. 
negativa do estrangeiro, do outro: o imigrante. Desde os anos noventa do século XX, a sociedade italiana é assediada televisivamente com os desembarques de imigrantes, primeiro de albaneses nas praias da Puglia (região que se encontra na parte sudeste da península) e, sucessivamente, de norte-africanos no sul da Sicília, eventos que são continuamente associados ao aumento da criminalidade e da falta de segurança pública. Diferentemente, com relação à esfera privada, a vida pessoal das entrevistadas se apresenta em um período muito positivo e elas se sentem, em graus diferentes, em um momento de serenidade e realização.

Um outro elemento importante, que caracteriza as entrevistas como um todo, é a forma como o grupo de entrevistadas, que não é composto unicamente por brasileiras, foi sendo construído. Não se organizou uma seleção anterior de indivíduos passíveis de serem entrevistados, mas se tomou a decisão de caminhar ao longo de uma rede composta pelas amizades construídas pelas próprias informantes. Cada uma das mulheres que participava da pesquisa indicava uma ou duas outras mulheres que estivessem dispostas a participar. Com esse procedimento, pôde-se ter acesso a uma rede de relações que extrapolava a clássica versão de entreajuda entre imigrantes de uma mesma localidade ou Estado Nacional.

O grupo que pouco a pouco se delineou era caracterizado por diferentes interesses, muitos deles vinculados ao lazer, local por excelência dos encontros e espaço-tempo onde essas mulheres travavam conhecimento. Por exemplo, Inês foi a pessoa que inseriu Helena na pesquisa e as duas tiveram o primeiro contato em um curso de florais de Bach. Dentro de suas dessemelhanças, essas mulheres apresentavam um perfil bastante homogêneo, inerente aos interesses que circundavam a rede e que as ligavam, mesmo que em maneira transversal. Todas elas chegaram de seus países (na América Latina) depois de terem concluído seus estudos universitários, eram provenientes de famílias de classe média ou classe média alta, viviam legalmente no país, não participavam de associações ou grupos de imigrantes e gozavam de uma boa integração social, mesmo que todas, de maneiras diferentes, analisassem criticamente a relação entre a sociedade italiana e os imigrantes. 


\section{Repercorrendo a experiência imigratória: entre férias e partidas, a chegada}

O percurso imigratório de Inês e de Helena tem início com um sentido de deslocamento transitório, de uma viagem, não de uma transferência definitiva para o exterior. Seja o caso de Inês, que tinha um sonho acalentado desde a adolescência de morar fora do Brasil, seja o caso de Helena, que embarca como acompanhante na viagem de estudos de uma amiga, a ideia era partir e retornar. De fato, vai ser a própria dinâmica da viagem que irá produzir a ampliação da permanência, a qual - mesmo tendo presente que Inês não a concebe ainda como definitiva - estrutura-se em um enraizamento na sociedade de acolhida.

Não é por acaso que o processo de transformação acontece no transcorrer da viagem, visto que essa vivência, como afirma Leed (1992), compõe um amplo território de metáforas que apresenta uma diversidade de signos vinculados à mudança, à transição e à transformação. As representações da viagem - desde aquela última, a morte, passando pelas descobertas, pelo encontro dos mais diferentes ambientes desconhecidos, pelo espaço, pela peregrinação - trazem consigo uma perspectiva de renovação. Está-se diante de um encontro com o diferente, o novo, talvez o inusitado, e isso vai provocar repensamentos, reflexões - muitas vezes, a vivência produz uma revisão do próprio curso da vida pessoal. Na narrativa das entrevistadas, a experiência da viagem constituir-se-á no momento de construção de uma ideia de imigração possivelmente por um tempo indefinido, ou ao menos de prolongamento da estadia.

$\mathrm{Na}$ construção desse ato de deslocamento, o viajante acaba se deparando ao menos com três ações consequenciais: partir, transitar, chegar. O primeiro passo constitui-se no ato de partir, o que significa abandonar - em definitivo ou temporariamente - um ambiente conhecido, pessoas que estão próximas, relações afetivas, seguranças. Viver e/ou reviver esse momento requer uma reflexão sobre as coisas que ficam (ficaram) para trás, é necessário fazer um balanço sobre a situação circundante para poder tomar a decisão de seguir adiante ou para justificar o fato consumado. O sentido hodierno da partida está intrinsecamente vinculado às coisas/pessoas/situações das quais o viajante se despe, mergulhando em um confronto psicológico que percorrerá com ele toda a viagem e, às vezes, permanecerá mesmo depois da chegada: "A partida 
contemporânea traz uma grande parte do próprio significado daquilo que é deixado para trás quando o viajor entra em uma situação moral e psíquica contrastante. A concepção da partida como "fuga' da civilização" (LEED, 1992, p. 59).

Em um certo sentido, a partida pode estar vinculada a uma fuga, seja de uma situação desastrosa economicamente seja de uma realidade psicologicamente sufocante, sendo possível relativizar a noção de civilização, saindo de um confronto clássico com um de seus contrários, a natureza, e relacionando-a em uma dimensão de experiências culturais diferentes. Se a maior parte dos estudos sobre as "partidas" imigratórias constrói-se a partir da esfera econômica - o antigo ditado de fare l'America -, o caso específico das mulheres estudadas traz à luz outras motivações, marcadas pela dimensão psicológica e que conduzem a um deslocamento inserido em um contexto de elaboração de imagens e representações sobre a experiência presente, em contraposição com as expectativas de futuro. Partir não é apenas um ato obrigatório que envolve a sobrevivência, mas é uma ação acalentada e desejada, como princípio de um processo de realização pessoal.

Para Inês, a partida apresentou-se como algo inusitado e - ao mesmo tempo - como realização de um sonho que ela trazia consigo desde a adolescência. Nascida em Santa Catarina, de uma família bem colocada econômica e socialmente, vivia havia muitos anos em São Paulo, antes da imigração, onde era sócia em um escritório de advocacia. Ela traz à tona, durante a entrevista, esse ressentimento acumulado entre um casamento precoce, aos 18 anos, seguido do nascimento de duas filhas e de um divórcio aos 30 anos:

Bom, essa decisão minha, ela nasceu praticamente de um sonho que eu tinha - desde adolescente - de morar fora do Brasil. É um sonho que eu achava que seria o máximo fazer essa experiência e por escolha - entre parênteses - erradas e precipitadas que eu tive, porque acabei casando com 18 anos - eu praticamente impossibilitei de realizar, para mim mesmo, esse sonho. E, depois de um casamento de 12 anos, no Brasil, do que resultam duas filhas, eu me separei e me divorciei, porque eu cheguei à conclusão que eu tava extremamente infeliz e aí eu comecei a me questionar: de ver o que eu queria fazer de minha vida, né, 
efetivamente, para ser feliz, o que eu achava que era importante (AHE, 2004).

Como parte de uma experiência comum ao seu grupo social, Inês ansiava por esse rito de passagem à vida adulta: a liberdade, um período de tempo fora do Brasil. No entanto, a não concretização desse desejo marcou-a profundamente, tanto que - terminado o casamento - ela não teve que pensar muito para concluir que retomar o seu sonho poderia ser um caminho "para ser feliz". A decisão da viagem está marcada por um presente caracterizado pela decadência, o final de um relacionamento de doze anos e um vazio existencial que impediam a entrevistada de perceber uma direção para sua vida. O seu drama pessoal acaba se constituindo no elemento movente ou propulsor para a saída do Brasil.

De qualquer forma, não é apenas a dimensão da perda que conduz Inês à Europa: a sua primeira partida e a escolha de seu primeiro destino estão entrelaçados com a descoberta de uma nova paixão. Logo depois do final de seu casamento, ela conhece - ainda no Brasil - um alemão e inicia uma relação. Quando ele retorna para a Alemanha, ela decide deixar tudo e seguir com ele, é a chance de estar com a pessoa que ela quer e - ao mesmo tempo - concretizar o seu sonho de morar no exterior:

E aí, eu resolvi retomar essa ideia de ter uma experiência, de viver fora do país. Isso foi impulsionado, obviamente, por uma paixão que eu tive - de um alemão que foi pro Brasil [riso] que foi pra mim um encontro, né, assim muito forte - próprio logo depois da separação - um tempo depois, esse cara, ele acabou, eu vim atrás dele na Alemanha, fiquei com ele aqui [uh] - em Berlim (AHE, 2004).

$\mathrm{Na}$ primeira escolha de um destino no exterior, Inês leva em conta o coração, mas pode-se dizer que o fato de estar deixando o país acompanhada, tendo alguém que pode ajudá-la a construir os primeiros relacionamento na terra de chegada, cria uma sensação de segurança que permite mais facilmente tomar a decisão de partir. Contudo, essa relação dura pouco, porque logo os dois chegam à conclusão de que "não iria dar certo", e ela se encontra novamente em uma encruzilhada: continuar essa experiência fora do Brasil ou voltar para casa. Vai ser nesse momento que 
a vinda para a Itália, sempre como uma experiência temporária, entra em seu horizonte de expectativas. De fato, ela conta que tinha duas possibilidades: uma prima que morava na Inglaterra e uma outra que vivia na Itália, em Florença. Mais uma vez o acaso - a primeira parente não estava em casa quando ela telefonou - faz com que Inês venha para a Toscana.

Chegando a Florença, em maio de 1999, Inês percebe que esse é efetivamente o lugar onde ela quer ficar. Ela fez, desde sua saída de Berlim, uma série de reflexões sobre o motivo de ter encontrado o rapaz alemão e ter deixado tudo para ir com ele para a Alemanha, e concluiu que o sentido de tudo o que acontecera era que ela devia, efetivamente, viver a sua experiência no exterior. Dentre as suas possibilidades de destino - pensando em um suporte familiar -, ela destaca que tinha Nova York, Londres e Florença, pois em cada uma dessas cidades tinha uma prima. Ao fim e ao cabo, a Itália acaba sendo escolhida por uma relação de empatia que se constrói desde o momento de seu desembarque.

No entanto, está-se diante de uma situação transitória, pois a entrevistada ainda está construindo uma ideia de emigração, considerando os prós e os contras de deixar o país e as consequências em âmbito familiar. Poder-se-ia dizer que essa é uma outra característica desse tipo de imigração: a construção de um processo efetivo de deslocamento, com reflexões que levam em conta, inclusive, uma experiência anterior no lugar que depois se escolhe como destino. Não se constitui em um fluxo migratório de grupo, pois são deslocamentos individuais, nem participa de uma rede de migrações internacionais, marcada pelas comunidades de entreajuda que vão se formando entre a terra de chegada e aquela de partida. Inês considera a presença de um parente, que pode servir de suporte e porta de entrada na nova sociedade, e a empatia construída desde sua chegada à Itália, pois a representação que ela tem do país está marcada por um estereótipo internacional que percebe os italianos como alegres, comunicativos, artistas:

quando eu cheguei aqui na Itália, eu tive certeza que era pra cá que eu tinha que vir, que era o lugar, assim, que me encantava, que tinha... que era muito poético. Depois, eu me identificava com os italianos pela alegria deles, pela... [...] pela disponibilidade, que... que são pessoas assim que eu de uma certa maneira achava que tinha ver com nossa característica de brasileiro, né, mais aberto (AHE, 2004). 
No mesmo ano, em 1999, ela volta para o Brasil e começa a tentar construir a sua partida "definitiva", considerando o que essa decisão poderia comportar em termos afetivos e econômicos, tendo em vista as suas filhas e o seu escritório de advocacia. Aliás, o componente materno vai ser aquele que mais pesará na decisão, ou na demora de uma tomada de decisão, pois ela não concebia a ideia de deixar suas filhas no Brasil e ir viver sozinha na Europa. Em um determinado momento, ela quase aceita o pensamento de que não poderia emigrar, pois, afinal de contas, tinha duas filhas. Porém, logo em seguida, resolve que tudo é apenas uma questão de organização:

obviamente, sair do Brasil, eu teria de trazer as minhas filhas, eu não ia deixar elas, entendeu... porque não tinha sentido, aliás, aliás, o fato de ter filhas foi um fato que eu adiei muito essa minha decisão, porque eu falava, bom, agora já não é mais o momento, porque eu já tenho filha, não é mais o momento, mas depois de vários questionamentos, eu falei: "Não, porque não é o momento", basta que eu me organize melhor, dá pra fazer também, né (AHE, 2004).

Tomada a decisão, a partida entra em uma nova fase, aquela do planejamento, pois como afirma a própria Inês, uma vez que estaria trazendo suas duas filhas, seria necessário que se organizasse tudo. Não querendo contar nada para ninguém, pois já se sentia muito pressionada pela família, ela começou a juntar dinheiro, colocou as filhas em uma escola italiana, em São Paulo, para que elas se acostumassem com a língua, com o ritmo, e para que entrassem no novo calendário escolar. E organizou um sistema de pagamentos de pró-labore com a sociedade da qual participava, que permitiria um rendimento depois da chegada na Itália.

Entretanto, nem todos os elementos da organização dependiam de sua ação pessoal, alguns estavam vinculados à boa vontade de instituições e de parentes. Não querendo emigrar ilegalmente, Inês tentou diferentes possibilidades junto ao consulado italiano para obter o visto de estudante, mas não obteve nenhuma solução. Diziam que ela não tinha idade ou que a sua formação não era compatível a uma continuidade de estudos no setor artístico, que era o que ela pretendia fazer.

Buscando estruturar sua chegada à Itália, entrou em contato com uma prima, aquela que a tinha recebido muito bem na outra estadia, 
temporária. Quando falou em partir de fato para morar na Itália, as coisas mudaram e sua prima elencou uma série de problemas que inviabilizariam a sua viagem: visto, dificuldade para arrumar uma casa, sustento. Inês não se deixou abater, fechou a casa e partiu com as meninas para Florença: "Tranquei a porta praticamente da casa, com tudo dentro, e peguei um avião e vim pra cá, com as meninas" (AHE, 2004).

Esse relato sobre a sua partida, sobretudo nos momentos mais fortes de tomada de decisão, permite perceber, pelos constantes usos de reforçativos como "entendeu" e "né", o ato de rememoração que vai progressivamente se decodificando na fala do entrevistado, seguindo um processo de transformação da experiência em linguagem, como destacado por Alberti (2004). O uso desses elementos confirmativos apresenta, por um lado, como que uma espera de ratificação da lógica da narrativa por parte do entrevistador, uma demonstração de que ele está compreendendo a trama do raconto, por outro, pede o assenso diante das decisões tomadas. É importante destacar sobretudo essa segunda questão, tendo em vista que a quantidade dos usos de "né" aumentava diante de problemáticas que envolviam um conflito moral. Os reforçativos colocam frente a frente emissor e receptor, sendo ao segundo solicitado o assenso diante das escolhas feitas pelo primeiro: da viagem para a Alemanha, da decisão de abandonar tudo e emigrar, de levar as filhas consigo, de manter-se ilegalmente na Itália.

A necessidade de reforço na fala é muito menos presente na narrativa de Helena e, quando acontece, frui mais em uma busca de diálogo explicativo, de uma confirmação sobre a compreensão do processo que está sendo relatado. $\mathrm{Na}$ análise dessa diferença na estruturação dos intercalares da narração, podem ser observados alguns elementos que indicam uma explicação para essa diversidade, marcados pela idade e pela vivência familiar, por um grau de maturidade emocional e afetiva diferenciados. Enquanto Inês tinha 37 anos no momento da entrevista e uma adolescência interrompida por um casamento prematuro, Helena já tinha 53 anos e, quando chegou pela primeira vez à Itália, em 1986, era solteira. Percebe-se também, na vida da catarinense, uma forte influência familiar, a qual é destacada em todos os momentos de decisão; diferentemente, a imigrante gaúcha não menciona em momento algum a busca de um conselho familiar ou a intromissão de parentes no período em que maturava sua decisão de viver na Toscana. 
Em um certo sentido, a partida de Helena coincide com aquela de Inês, tanto no que se refere à casualidade da primeira partida quanto no que se relaciona ao planejamento da emigração definitiva. A segunda entrevistada chegou à Itália em um momento muito diferente, no que tange, sobretudo, aos preconceitos com relação aos imigrantes, em 1986, e teve uma experiência muito mais tranquila nesse sentido. Natural de Passo Fundo, Helena era professora pública de Educação Artística, em Porto Alegre, e oferecia cursos relacionados com a sua área na Casa de Cultura Mário Quintana. Ela também tinha seu apartamento, onde morava sozinha, mas não forneceu informações sobre a sua vida afetiva e/ou familiar antes do deslocamento para a Itália.

A gaúcha não havia planejado uma viagem para o exterior, tampouco para a Península Itálica; efetivamente, essa ideia não estava presente em seu horizonte de expectativas, o seu destino parecia ser a rotina de seu dia a dia porto-alegrense. O elemento propulsor está em um convite feito por uma amiga, que estava organizando uma viagem de estudos para a Itália. Em uma conversa entre as duas, a amiga pergunta se ela não gostaria de ir junto, e em uma resposta irrefletida, Helena diz que sim:

Tudo começou mais ou menos assim, de brincadeira. Eu trabalhava com uma guria que estava terminando a escola de artes e queria continuar seus estudos, queria fazer um curso de aprofundamento no exterior. Procurou alguma coisa e achou a Itália como aquilo que lhe agradava naquele momento. Enquanto estava preparando tudo, me disse assim: “Tu vens também”? Eu disse: "sim", mas sem nenhuma convicção, não me passava pela cabeça a ideia de fazer uma viagem a um lugar tão distante, por nada. Eu disse de brincadeira (VBK, 2004) ${ }^{2}$.

O tempo foi passando, Helena foi fazer o passaporte, sempre a convite da amiga, mas tudo ainda estava muito nebuloso, ela não se imaginava deixando tudo e partindo para a Itália. Somente na fase posterior,

2 Helena preferiu conceder a entrevista em italiano, pois afirmava que conseguia se expressar melhor na nova língua, tendo perdido um pouco a fluência em português. Dessa forma, os fragmentos apresentados são uma tradução feita pelo autor, partindo do texto original. 
quando sua amiga disse que deveriam comprar a passagem, é que ela percebe que a viagem é algo concreto e que está se encaminhando para uma experiência no exterior. Também nesse caso, torna-se necessário um planejamento e uma organização da vida profissional, tendo em vista que a entrevistada era funcionária pública e sócia em uma confecção.

Como relata a depoente, todo o processo aconteceu por acaso, como se fosse um jogo, como se tudo fosse fruto da projeção de um período hipotético de férias. No entanto, o momento da compra de uma passagem anual desconstrói a imagem de fábula que circunda a história e coloca-a no plano do real: a viagem tem início de fato. Helena pede um período de licença na Secretaria de Educação do estado do Rio Grande do Sul, termina a sociedade que tinha na confecção de vestidos e aluga o seu apartamento. Nesse momento, dá-se o início de seu trânsito, ou de seu primeiro deslocamento, já que sua partida não termina nesse momento.

A primeira viagem de Helena estrutura-se como uma grande epopeia, no melhor estilo das narrativas gregas, pois qual Ulisses que se encaminha com dificuldade para Ítaca, enfrentando uma travessia que parece não ter fim, ela dá início a um trânsito que dá a impressão de ser infinito. Como ela mesma raconta, devido às dificuldades de overbooking, muito comuns naquele período, ela vai passar diversos dias em viagem, desembarcando em diferentes cidades:

Para partir e para chegar aqui, tivemos que passar por Portugal, onde eu tinha um amigo, que tinha vindo antes e que estava ali. Então, tivemos um pouco de férias. Ficamos ali por um período, até que tivéssemos um voo para chegar aqui, em Florença. Depois, tivemos que ir para Madri e, depois de Madri, viemos para Florença. Então, passando por esses dois lugares, onde ficamos por uma semana, eu observei um pouquinho como eram as coisas em, assim, muito en passant. Quando cheguei em Florença, aahh, me sentia como se tivesse chegado em casa, um lugar maravilhoso. Fiquei tão emocionada com essa coisa. Mas por muito tempo! Todos os dias - ai ai - era quase como se eu tivesse retornado em um lugar maravilhosos e vivia então aquela alegria, assim, que estava presente em mim, que eu não conseguia entender de onde provinha. Era de fato uma coisa interior, assim, muito grande (VBK, 2004). 
A narrativa da primeira partida de Helena ilumina alguns elementos que funcionam como tropos de uma literatura de viagem, a qual apresenta o momento de trânsito como ampliação dos conhecimentos do viajor, tendo em vista o contato com a diferença e, ao mesmo tempo, como transformação de suas qualidades intelectuais. Nesse processo, como vai acontecendo na medida em que a entrevistada percorre e/ou repercorre sua trajetória, o deslocamento assume pouco a pouco o espaço de mudança, a travessia constitui-se na sedimentação e na construção/concretização da viagem:

A viagem altera a relação do viajante com o lugar, e o que se deve compreender é como essa transformação da relação com o mundo, operada pela viagem, influencia a mentalidade, a personalidade, as relações do próprio viajor (Leed, 1992, p. 77).

Assim como Inês, também Helena vai construir uma perspectiva de emigração ao longo da sua primeira viagem. A interação entre as diferentes fases dos seus deslocamentos permite perceber o fermento de mudança que a experiência da travessia e as experiências na travessia trazem consigo. Retornando à discussão sobre as vivências do presente do entrevistado, percebe-se que o movimento físico e o contato com outras realidades culturais exercem um grande poder no processo de leitura que o viajante elabora sobre o seu próprio percurso; no caso das entrevistadas, construiu o seu desejo de emigrar:

Este exame dos momentos fundamentais da viagem - a partida, o trânsito e a chegada - busca construir uma imagem aceitável da força e do poder exercidos pela mobilidade territorial sobre a psique humana, sobre as concepções do eu, do outro e das relações humanas (Leed, 1992, p. 77).

Nesse sentido, poder-se-ia dizer que o processo de transformação que irá conduzir à chegada, para Inês, inicia-se quando de seu primeiro contato com Florença, mas realiza-se, efetivamente, em sua segunda vin$\mathrm{da}$, no momento em que começa um relacionamento com um jovem italiano, compra casa e conclui (ao menos temporariamente) o seu trânsito. Para Helena, a chegada também comportará uma nova partida, pois tem 
início com o primeiro contato, quando também conhece um italiano, mas termina - depois de uma tentativa de viverem juntos no Brasil - com um casamento e uma estabilização em San Giovanni Valdarno, província de Arezzo.

\section{Entre o sonho e a experiência: algumas leituras sobre a terra de chegada}

O processo de imigração constrói, inexoravelmente, ao menos duas leituras possíveis sobre a terra de chegada: uma marcada pela experiência indireta de imagens e narrativas que chegam aos sujeitos através de diferentes expedientes (amigos, meios de comunicação), mesmo antes que eles maturem uma ideia de partida, e outra assinalada pelo contato físico, pela vivência direta com o país de imigração. Nas duas situações está-se lidando com representações que vão se construindo através de fragmentos do real, sejam eles relativos a informações de segunda mão ou a experiências efetivas do espaço. No primeiro caso, levando em consideração a relação que se estabelece entre o presente e a memória, o indivíduo, na medida em que se encontra desestimulado com relação ao seu entorno, percebe o novo lugar com uma lente de encantamento, com os óculos que usa o viajante para observar a sua viagem, que enxerga em um contraste com a representação produzida mentalmente (Brilli, 2006). No segundo caso, percebe-se um processo de alteração, o qual, mesmo não criando o desencanto, progressivamente conduz a uma leitura crítica da realidade: o viajante passa a ser imigrante.

No momento da partida, como relatado tanto por Inês quanto por Helena, a ideia de viajar para a Itália traz consigo a dimensão de uma busca de descanso, de um período de férias. Procura-se romper com a rotina e com um quotidiano marcado pelo desencanto, pela mesmice, pelos sonhos irrealizados, para viver, dessa forma, novas experiências, concretizar novos desejos. Nesse sentido, a Itália - considerando as representações que circulam internacionalmente - parece o lugar ideal para a busca da felicidade e da serenidade, como já diziam os peregrinos do famoso "viaggio in Italia", percurso formativo obrigatório para todo jovem de boa família, entre os séculos XVI e XIX.

Inês oferece alguns indícios dessa percepção extremamente positiva da península quando comenta os sentimentos que a fizeram se sentir 
tão bem em uma primeira estada na Itália e, ao mesmo tempo, as possibilidades que se apresentariam, no momento em que ela estivesse vivendo naquele país. Por um lado, como relata, a população italiana se assemelha muito àquela brasileira, porque as pessoas são abertas, expansivas, disponíveis; por outro, viver na Itália ofereceria uma ocasião ímpar para um aprofundamento da história da arte, outra ideia-imagem relacionada à terra de Raffaello e Michelangelo:

a ideia da dona Inês era chegar aqui e fazer um curso de história da arte, fazer um curso assim, já que eu vinha pro berço do renascimento. Eu falei: "Bom, vou fazer um curso, vou mergulhar numa coisa do renascimento, de arte, de etc. (AHE, 2004).

Também para Helena, com a primeira viagem, esse maravilhamento não se desfaz, pelo contrário, como ela diz, tudo era emocionante, fascinante, produzia uma sensação de viver efetivamente um sonho. Está-se ainda diante da rememoração de um viajante, mesmo tendo claro que em toda a narrativa das imigrantes é constante a construção de uma justificativa para as escolhas feitas, e a leitura da experiência vivida na nova terra ainda apresenta a força das representações construídas no momento anterior à saída do Brasil. Como dizia o viajante Creuzé de Lesser, relatando sua viagem pela Itália no início do século XIX, o viajor enxerga com dinâmicas mentais que estão presentes enquanto representações apriorísticas ao fato concreto da partida e do trânsito:

Os viajantes que descreveram a Itália, que vieram neste país para contar uma viagem e com a determinação de encontrar e pintar todo tipo de beleza, normalmente começaram a prefigurá-la na imaginação, depois a admirá-la; trata-se de pessoas que colocaram um par de óculos verdes e, dessa maneira, viram tudo verde (Brilli, 2006, p. 371).

Junto a esse olhar, um outro elemento bastante relevante na construção desse deslumbramento dos primeiros tempos é caracterizado pela sensação de liberdade e renovação que a nova situação permite. De uma certa maneira, o imigrante - deixando suas relações na terra de partida, assim como os seus problemas - contempla esperançoso uma nova vida e um novo "eu" que se descortinam em sua frente. Existe uma grande 
sensação de aprendizagem, de transformação, de movimento, que impede, inclusive, de construir apreciações objetivas, como, por exemplo, no que se refere à esfera laboral, sobre o tipo de trabalho que deixa na terra de partida e aquele que se começa a fazer no país de destino. Em Florença, Helena se sente feliz trabalhando vinte e quatro horas por dia e recebendo somente casa e comida, como não se sentia quando trabalhava como professora pública em Porto Alegre.

Analisando a situação de uma maneira mais "objetiva", surge de maneira espontânea a pergunta: como ela podia se sentir realizada com uma situação profissional e de status social tão piorada? Um indício possível para se vislumbrar uma resposta pode ser encontrado nessa sensação de liberdade, fortemente descrita por Helena, no fato de não se existir burocraticamente:

Quando cheguei aqui, a possibilidade de ser invisível era uma coisa maravilhosa, ou seja, não tendo um número, nenhum número, não tendo necessidade de uma conta corrente, de correr para lá, de pagar isso, o cartão e todas essas coisas. Esta liberdade de não ser é tão maravilhosa, depois de um pouco todas essas coisas são necessárias e então começa a pesar (VBK, 2004).

A Itália estava se construindo como o mundo das brincadeiras, o trabalho não deixava de ser um jogo necessário para a subsistência, mas não estava marcado pela burocracia que envolve as relações trabalhistas. De fato, não existiam relações formais, ela vivia uma troca, oferecia aquilo que possuía, a força de trabalho, e ganhava como compensação os meios para a sua subsistência e a possibilidade de manter o contato com o lugar mágico que havia descoberto. Enquanto o Brasil era o lugar da falta de tempo, da opressão de um ritmo acelerado de atividades que não faziam parte de suas escolhas pessoais, mas de obrigações, a Itália era o espaço do lazer, onde se podia fazer as coisas que se tinha vontade. A nova experiência produz, também, um olhar crítico sobre a vivência anterior, as relações se tornam ainda mais opressivas, não se consegue compreender como se conseguia suportar uma existência tão escravizada por uma repetição monótona de atividades e pelas regras:

Esta coisa me oprimia tanto antes e, então, essa liberdade aqui era uma coisa maravilhosa, tudo era maravilhoso... isto é, eu era eu e 
tinha o meu nome e basta... não tinha números, não tinha nenhum compromisso, não... com uma liberdade muito grande. Internamente, eu sentia muita falta disso, como eu tinha chegado em um ponto assim, de ter todos aqueles compromissos [sic] como eu me libertei. Ter a jornada disponível para fazer aquilo que se tem vontade, eu não tinha no Brasil. Eu tinha um ritmo tão estressante, nem mesmo nas férias me acontecia uma coisa igual (VBK, 2004).

Inês, mesmo não apresentando uma reflexão sobre a sua vida antes e depois da partida, apresenta um quadro de contraste entre o seu dia a dia em São Paulo e a nova experiência de vida no campo. Na sua descrição do lugar que sua prima encontrou para que ela ficasse hospedada, próximo à cidade de Florença, ela constrói a imagem de um espaço bucólico, rural, também a representação de um tropos de liberdade:

um apartamento num agroturismo, num lugar lindíssimo que tem ali, perto de Comeana, praticamente é Comeana, onde tem Artiminio, próprio ali pertinho de Firenze, que é na campanha, mesmo, assim, no campo, de uma... se chama Villa Vittoria, onde eles têm plantação de oliva e de vinho, etc... E eles tinham feito esses apartamentos pra estrangeiros mesmo, pra ficar pouco tempo, pra contratos que venciam a cada 6 meses, que eram interessantes pra eles, né, e pra mim também (AHE, 2004).

Pela descrição da paisagem e com um pouco de conhecimento da Toscana, pode-se imaginar um espaço no alto de uma colina, circundado por oliveiras e vinhedos, em um retrato de paz e tranquilidade, em harmonia com a natureza. Obviamente, isso se constituía no extremo oposto de São Paulo, metrópole frenética, representada pelo movimento de pessoas, de carros, de máquinas, senhora de um vai-e-vem constante. Nesse novo espaço, certamente muito custoso, ela inicia sua nova rotina, em um novo ritmo, na terra de acolhida. Parece que tudo está se ajustando, pois mesmo as filhas, que no início se sentiam perdidas no novo ambiente, com saudades do Brasil, começam a se adaptar e a construir novos relacionamentos.

Esse momento de trânsito é ainda marcado por uma outra experiência positiva, que aumenta a sensação de satisfação com relação à nova 
realidade, o encontro de um companheiro. As duas entrevistadas, logo depois de sua chegada em Florença, conhecem a pessoa com a qual passam a viver. No caso de Helena, será o seu professor de ioga, conhecido quando ela começa a organizar o seu dia a dia em Florença, retomando as atividades agradáveis que estava habituada a realizar em Porto Alegre. Já Inês encontrará seu companheiro em uma danceteria, quando ela decide sair para dançar, rompendo com a sua rotina de dona de casa. Esses encontros serão muito importantes para ambas, pois conduzirão a um processo de mudança na condição das duas mulheres, encaminhando sua estadia transitória em direção a uma efetiva chegada.

Depois desse encontro, Inês retorna ao Brasil apenas para apresentar o seu futuro marido aos familiares, pois em pouco tempo eles tomaram a decisão de contrair matrimônio, uma vez que logo depois que se conheceram, por causa do término do contrato de locação do apartamento de Inês, foram viver juntos, na casa do companheiro. Diferentemente, Helena ainda retornou ao Brasil, pois sua situação profissional não tinha sido resolvida e a sua licença havia terminado. Em um primeiro momento, tentam viver juntos em Porto Alegre, mas por questões financeiras e por uma forte não-adaptação, ele retorna para a Itália. Acabam se casando por procuração, pois uma informação errada faz Helena pensar que com o casamento ela poderia se transferir para a Itália sem perder o emprego. O mal-entendido acaba se resolvendo, o casamento a distância não serve para a manutenção do cargo e ela larga tudo no Brasil, viajando definitivamente para Florença.

Nessa segunda fase, quando terminam "as férias" e tem início a vida real, quando elas tomam consciência de que a viagem de fato terminou e que elas chegaram ao destino final, percebe-se um processo de transformação nas representações que elas constroem sobre a Itália e nas próprias comparações entre a terra de partida e aquela de chegada. Inês expressa abertamente essa mudança em sua percepção do italiano, quando, falando de seu marido, afirma que ele é uma pessoa muito querida, é um italiano diferente:

porque ele é realmente, ele é muito querido, ele é, ele é, eu digo até que é um italiano diferente. Porque eu tinha essa ideia do italiano ser aberto, etc... Morando aqui, eu vi que não é nada disso. Que é muito diferente, entendeu. E... mas ele é assim, ele realmente é 
assim. Então, ele tem muito de brasileiro, assim, nessa abertura e nesse carinho, de ser chegado, assim, nas pessoas (AHE, 2004).

A vivência quotidiana foi rompendo algumas ideias-imagens que estruturavam uma representação da terra de chegada, na fase anterior ao contato direto como morador, não apenas como turista. Na realidade específica de Inês, a situação se apresenta em uma maneira muito mais dramática, pois ela convive com uma aceitação apenas formal de seu relacionamento por parte da família do marido, que, no caso da cunhada, acabou se transformando em um afastamento total. Em parte, isso está vinculado, segundo a sua percepção, ao fato de ela ser brasileira - muito embora as coisas tenham melhorado depois que o marido foi conhecer a sua família, mostrando, através das fotos, uma situação de bem-estar em que esta vivia. Certamente, nesse comportamento se evidencia uma representação muito negativa vinculada à mulher brasileira, a qual diminui com a tomada de conhecimento da boa situação econômica que goza a família da entrevistada. Além da questão da nacionalidade, a diferença etária - Inês é sete anos mais velha que o marido - e o fato de ela ser separada e com filhos têm um peso importante na avaliação negativa que é feita sobre ela.

Mais uma vez a experiência - neste caso vinculada ao vivido presente - afeta as expectativas e as percepções. A Itália começa a perder o seu encanto e o lugar de sonho começa a ser identificado com o Brasil. Ela, no momento da entrevista, estava chateada porque não conseguiria, por um erro da agência de viagens, passar as festas de final de ano no Brasil e comentava a sua vontade de retornar, para ir morar em Florianópolis. Todavia, entendia as dificuldades para a realização desse seu desejo, pois - por causa do tipo de trabalho que fazia seu marido - eles nunca conseguiriam ter um nível de vida igual àquele vivido na Itália. De qualquer forma, ela se lamentava da falta de eventos culturais, que absolutamente não imaginava quando estava no Brasil, de lugares de divertimento, que em São Paulo existiam em abundância, e do fato de os lugares não ficarem abertos até tarde, ao passo que no Brasil existiam lugares que nunca fechavam. Os fragmentos que compõem o seu novo quebra-cabeças com a imagem da Itália começam a apresentar algumas peças com uma coloração mais negativa sobre a terra de chegada.

Helena, de uma maneira menos acentuada e sem fazer explicitamente comparações, também apresenta um processo de alteração em seu modo de ver a sociedade italiana, sobretudo no que se refere à relação 
com os imigrantes e à percepção da mulher brasileira. Como se comentou anteriormente, ela viveu um processo diferenciado, porque a imigração não era ainda um fenômeno importante, na Itália, nos anos 80, mas mesmo assim - ela acusou essa diferença de percepção.

Uma questão destacada por ela, que se assemelha aos elementos que contribuem para a mudança na atitude mental de Inês com relação à terra de acolhida, refere-se aos estereótipos da brasilidade. O preconceito e as generalizações vinculados à representação construída na Itália sobre a mulher brasileira foram experimentados e observados pela entrevistada. Helena comenta as transformações que aconteciam em um diálogo corriqueiro, nos mais diferentes locais, quando o interlocutor tomava conhecimento de que falava com uma brasileira:

depois de um pouco de tempo, este compreende que tu és estrangeira e pergunta: "de onde és? - "do Brasil" - a conversa muda completamente, muda completamente - é uma coisa que acontece com muita, muita frequência. Se tornam indiscretos, mal-educados, algumas vezes... é uma pessoa assim, educada, um minuto depois, mal-educada (VBK, 2004).

A entrevistada destaca, também, a relação de exploração que se constrói no bojo da sociedade da terra de chegada. Em sua fala, que diferencia os imigrantes temporários, que não fazem outra coisa senão pensar na terra que deixaram, e aqueles "definitivos", que buscam, como ela, construir uma nova vida, Helena apresenta como inquestionável o caráter exploratório da população autóctone, recordando que aqueles que decidem viver apenas para acumular dinheiro para retornar para seus países partilham de um mesmo raciocínio de exploração: "se tu vens para ficar por um período e acumular dinheiro. Ou seja, tu fazes a mesma coisa que eles, uma exploração, então, a relação é equilibrada nesta regra: eu te exploro e tu me exploras" (VBK, 2004).

Observa-se que a experiência marcada pela vivência quotidiana na terra de chegada provoca um processo de mudança no que se refere à percepção dessa terra. Se em um primeiro momento o imigrante está envolvido por um conjunto de representações, que participam de estereótipos internacionais, que classificam e dão a conhecer a sociedade de acolhida, posteriormente ele começa a adentrar nas vicissitudes mais profundas da 
nova realidade e a perceber outros fragmentos do real, que conduzem a uma complexificação de sua análise e à relativização daquele seu pleno encantamento vivido nos primeiros tempos.

\section{Considerações finais}

No contexto das migrações internacionais contemporâneas, tem-se observado um progressivo aumento da participação brasileira, com um crescimento maior a partir da virada do milênio, e uma tendência a transformar a Europa em um importante centro receptor de imigrantes provenientes do Brasil. Dentro dessa realidade, são muito poucos os estudos que buscam dar conta de uma imigração "comum", não marcada pela ilegalidade ou pela criminalidade, uma imigração marcada por indivíduos de classe média que buscam a realização de aspirações pessoais, muitas vezes não pautadas explicitamente pelo elemento econômico. Certamente, mesmo quando a questão econômica se apresenta, ela não se constrói a partir de uma necessidade imperativa de partir para sobreviver.

A partida, fruto de uma escolha pessoal, de um planejamento, não se constitui especificamente em um momento de perda, mas a mente está já voltada para o destino final da viagem, analisando os benefícios que a experiência, pensada em um primeiro momento como transitória, pode comportar. Diferentemente dos processos imigratórios que implicam uma partida "obrigatória", por razões de sobrevivência, a separação da terra natal não é uma punição, pelo contrário, o deslocamento é concebido como um prêmio e a terra de chegada se apresenta como a imagem do espaço ideal para a realização dos sonhos.

Pouco a pouco, o trânsito se transforma efetivamente em imigração e a experiência que nasce como temporária assume uma dimensão, em teoria, definitiva, sendo que essa nova situação produz uma progressiva transformação na percepção que o ex-viajante tem sobre a terra de chegada. O lugar dos sonhos, imagem que contribui para a construção de sua decisão de partir, começa a ser corrompido por experiências diretas ou indiretas que promovem o encontro com uma alteridade negativa. Em alguns casos, essa "piora" no modo como o imigrante enxerga a sociedade que o acolhe promove um deslocamento espacial do seu lugar encantado, o qual acaba sendo encarnado pela terra de partida. 
O fenômeno imigratório é um processo complexo, no qual se entrecruzam diferentes fatores econômicos, sociais e culturais, relacionados com os diversos grupos que se inserem no grande movimento das migrações internacionais. Nesse sentido, é importante dar voz, também, a uma imigração que não ocupa os meios de comunicação, pois não é composta por indivíduos que vivem à margem da sociedade, criando notícia, mas que - muitas vezes - se encontram "invisíveis" no seu interior. Contudo, também vivem a experiência do deslocamento, da xenofobia, da perda, mesmo que em formas menos midiáticas, mas não menos dolorosas, nas relações interpessoais que marcam a vida quotidiana. Descortinar essas facetas da imigração, retirando-as da sobra do esquecimento, é abrir um espaço mais plural nas discussões internacionais, permitindo a construção de um quadro mais representativo desse processo.

\section{Entrevistas}

AHE. Entrevista realizada por Luís Fernando Beneduzi em 8 de novembro de 2004, em Loro Ciufenna (Arezzo). Conservada no audioarquivo sobre as migrações entre a Europa e a América Latina (AREIA), Gênova.

VBK. Entrevista realizada por Luís Fernando Beneduzi em 16 de novembro de 2004, em Terranuova Bracciolini (Arezzo). Conservada no audioarquivo sobre as migrações entre a Europa e a América Latina, Gênova.

\section{Referências bibliográficas}

ALBERTI, Verena. Ouvir contar: textos em História Oral. Rio de Janeiro: FGV, 2004.

BACZKO, Bronislaw. Los imaginarios sociales: memorias y esperanzas colectivas. Buenos Aires: Ediciones Nueva Visión, 1991.

BENEDUZI, Luis Fernando. Alguns lugares de memória do processo diaspórico: narrativas de mulheres brasileiras e argentinas na Itália contemporânea. Revista Tempo e Argumento, n. 2, v. 1, Florianópolis, 2009.

BRILLI, Attilio. Il viaggio in Italia. Storia di una grande tradizione culturale. Bologna: Il Mulino, 2006.

GRELE, Ronald. Introduzione. In: PORTELLI, Alessandro. Storie Orali. Racconto, immigrazione, dialogo. Roma: Donzelli Editore, 2007. p. VII-XV. 
LEED, Eric. La mente del viaggiatore. Dall'Odissea al turismo globale. Bologna: Il Mulino, 1992.

LEONINI, Luisa. Sesso in Acquisto. Os clientes das prostitutas. Algumas reflexões a respeito de uma pesquisa sobre a prostituição em Milão. In: SCHPUN, Monica. Masculinidades. São Paulo: Boitempo, 2004. p. 70-107.

MACHADO, Igor José de Renó. Afetividade e poder entre os imigrantes brasileiros no Porto. Cadernos Pagu [online] n. 23, 2004, p. 257-278.

PISCITELLI, Adriana G. Industria del sexo y mercado matrimonial: la migración brasileña hacia Italia en el marco del turismo sexual internacional. In: HERRERA, Gioconda; RAMIREZ, Jacques. (Org.). América Latina migrante: Estado, família, identidades. Quito: FLACSO, 2008. p. 231-257.

. Sexo tropical em um país europeu: migração de brasileiras para a Itália no marco do "turismo sexual" internacional. Estudos Feministas, 15(3), set./dez. 2007, p. 717-744.

PONTES, Luciana. Mulheres brasileiras na mídia portuguesa. Cadernos Pagu [online] n. 23, 2004. p. 229-256.

Resumo: A grande maioria das pesquisas que buscam discutir o processo imigratório feminino brasileiro na Europa tem dado ênfase a uma dinâmica caracterizada pela ilegalidade e pela "criminalidade". O objetivo deste artigo, parte de um percurso mais amplo de pesquisa que busca analisar as imagens de nação e as narrativas sobre a expatriação construídas por imigrantes argentinas e brasileiras, é discutir a experiência do processo imigratório vivida por mulheres de classe média, com um nível universitário de instrução, que decidem deixar o Brasil e procurar uma realização profissional, pessoal e/ou existencial no exterior. Neste caso específico, trabalhar-se-á com imigrantes brasileiras que vivem atualmente na Itália e que imigraram entre a década de 1980 e o início do novo milênio.

Palavras-chave: emigração brasileira; imigração latino-americana na Europa; memória; representação; identidade.

Narratives of a forgotten immigration: images, choose and percursos of a Brazilian women immigration in Italy

Abstract: Most research about the Brazilian female immigratory process in Europe emphasises a dynamic characterized by illegality and "criminality". The target of this paper, as part of a larger research track that tries to analyse images of the nation and narratives about the expatriation process from Argentine and Brazilian women immigrants, is to discuss the experience of the immigration process in middle class and university-educated Brazilian women that decide to leave the country and look for professional, personal or existential realization abroad. In this specific case, we will work with Brazilian women immigrants that are living in Italy and arrived there between the 80's and the beginning of the new millennium.

Keywords: Brazilian emigration; Latin America immigration in Europe; memory; representation; identity. 